\title{
MECHANICAL FAILURE OF MULBERRY AND TASAR SILK
}

\author{
Subrata Das' \\ ' Department of Fashion Technology, \\ Bannari Amman Institute of Technology, Sathyamangalam, India \\ *e-mail: subratactl@gmail.com
}

\author{
Scientific paper \\ UDC: $677.1 / .2: 620$ \\ doi: $10.5937 /$ tekstind2102016D
}

\begin{abstract}
This article investigates the tensile and twist failure of mulberry and tasar silk filaments. The mulberry and tasar filaments were subjected to uniaxial loading on Instron tensile tester at different rate of extensions and gauge lengths. Furthermore, the number of turns to rupture the silk filaments was tested using a twist tester. The results showed that the mulberry filament has higher tensile and twist strength than that of tasar filament. The SEM photomicrographs of the region of fracture divulged that the tensile and twist failure of mulberry and tasar filaments take place in catastrophic and non-catastrophic modes, respectively.
\end{abstract}

Keywords: Mulberry silk, tasar silk, tenacity, twist to break, fracture morphology.

\section{MEHANIČKI KVAR MULBERRY (DUDOVE) I TASAR SVILE}

\begin{abstract}
Apstrakt: Ovaj rad istražuje zatezanje i uvrtanje svilene niti duda i tasara. Niti duda i tasara bile su podvrgnute jednoosnom opterećenju na Istron ispitivaču zatezanja pri različitim stepenima ekstenzije i mernim dužinama. Štaviše, broj obrtaja za pucanje svilenih niti testiran je pomoću testera za uvijanje. Rezultati su pokazali da dudov filament ima veću zateznu i zavojnu čvrstoću od tasar filamenta. SEM fotomikrografije područja preloma otkrile su da se zatezanje i uvijanjeniti duda i tasara odvijaju u katastrofalnom i nekatastrofalnom režimu, respektivno.
\end{abstract}

Ključne reči: Mulberry (dudova) svila, tasar svila, izdržljivost, uvijanje do pucanja, morfologija preloma.

\section{INTRODUCTION}

Silk fiber is recognized as queen among the textile fibres. The history of silk fibre dates back to roughly 5000 years, since then it remains an important luxurious textile material for its elegant aesthetic look [1]. Moreover, silk fibre has outstanding potentiality as a structural material because of its unique combination of strength and ductility compared to any other natural fibres. Despite of this fact, the reported work on the tensile failure mechanism of silk filament is not adequate $[2,3]$.

The strength of any textile material is largely governed by two important testing parameters viz., extension rate and gauge length [4]. To the authors' knowledge, no information is available on the effect of extension rate and gauge length on silk filament.

High twisted silk filaments are often used to produce crepe fabric to have crinkle effect for specific end uses. But if a silk filament is twisted beyond a certain level, it will eventually break [5]. Therefore, it is interesting to see the maximum value of twist a silk filament can withstand before its rupture. Literature hardly reports anything with reference to the rupture of silk caused by twist.

So, the present investigation was mainly focused with a view to studying the aforementioned aspects 
of silk filaments produced by two common silkworms, namely, mulberry (Bombyx mori) and tasar (Antheraea mylitta D.).

\section{EXPERIMENTAL}

\subsection{Materials and preparation}

Mulberry and tasar silk cocoons were collected from Central Silk Technological Research Institute, Central Silk Board, Bangalore, India and Raw Material Bank, Chaibasa, Bihar, India, respectively. Cocoons were softened and reeled by following different procedures for mulberry and tasar silk as described elsewhere [6]. This was required to obtain mulberry and tasar silk filaments.

The mulberry cocoons were taken in a wire mesh cage and softened in the first pan at $65^{\circ} \mathrm{C}$ for one minute, then in the second pan at boiling for about one and half minutes, and finally at $65^{\circ} \mathrm{C}$ for one minute. The softened cocoons were hand-brushed at boiling in order to obtain the true end of the filament. Due to the hard and compact nature of the tasar cocoons, softening with $10 \%$ ethylenediamine was required at $80^{\circ} \mathrm{C}$ for $50 \mathrm{~min}$. The cocoons were deflossed manually to obtain the true end of the filament. Both mulberry and tasar filaments were degummed with 25\% Marseilles soap (on the weight of the material) at boil for $90 \mathrm{~min}$ at a liquor ratio of 50:1. The degummed filaments were washed, dried and conditioned at tropical atmosphere of $27^{\circ} \mathrm{C}$ and $65 \%$ relative humidity (according to ISO 139-1973 IE, s.2.3.1) for 48 hours. The deniers of the mulberry and tasar filaments were obtained 9.5 and 10 , respectively. Subsequently, these filaments were evaluated for tensile and twist failure.

An Instron tensile tester was used to study the tensile behavior of mulberry and tasar filaments. The filaments were tested at different rate of extensions, viz., 50, 100, 200, 300 and $500 \mathrm{~mm} / \mathrm{min}$ at a constant gauge length of $100 \mathrm{~mm}$. The filaments were also tested at different gauge lengths $(20,50,100,250$ and 500 $\mathrm{mm}$ ) at a constant extension rate of $200 \mathrm{~mm} / \mathrm{min}$. For each set of experiment, 50 tests were conducted.

The number of turns to rupture the silk filaments was studied using a twist tester. A nominal gauge length of $250 \mathrm{~mm}$ was used in the twist tester. The counter was set at zero. The sample was mounted between the clamps under a tension of $2.5 \mathrm{cN} / \mathrm{tex}$. One end of the specimen was secured in the nonrotatable clamp and the other end of the specimen was inserted through the rotatable clamp. The filament was slowly extended through the open clamp until the pointer attached to the nonrotatable clamp reached the re- quired tension. The rotatable clamp was revolved either in clockwise or anticlockwise directions until the filament breaks. The number of turns per inch (TPI) to rupture the silk filaments was measured from the counter. The average number of TPI to break was calculated based on 30 readings in each case.

After the tensile and twist failure of the filaments, the broken ends were collected and characterized by scanning electron microscope (SEM).

\section{RESULTS AND DISCUSSIONS}

Tenacity of both mulberry and tasar filaments tested at different extension rates are given in Table 1.

Table 1: Tenacity of mulberry and tasar filaments at different extension rate

\begin{tabular}{ccc}
\hline $\begin{array}{c}\text { Extension } \\
\text { rate }(\mathrm{mm} / \\
\mathrm{min})\end{array}$ & \multicolumn{2}{c}{ Tenacity (cN/tex) } \\
\hline 50 & $\begin{array}{c}\text { Mulberry } \\
\text { filament }\end{array}$ & Tasar filament \\
\hline 100 & $33.2(8.0)^{*}$ & $27.4(7.8)$ \\
200 & $34.6(8.8)$ & $28.5(6.9)$ \\
300 & $38.7(6.9)$ & $30.1(6.7)$ \\
500 & $39.3(8.4)$ & $31.4(8.6)$ \\
\hline
\end{tabular}

"Values in the parenthesis indicate the $\mathrm{CV} \%$ of tenacity

It is clearly demonstrated that the strength for both the filaments is an increasing function of extension rates. A 10 -fold increase in extension rate, i.e., from $50 \mathrm{~mm} / \mathrm{min}$ to $500 \mathrm{~mm} / \mathrm{min}$, produces $18.4 \%$ and $14.6 \%$ increase of strength values for mulberry and tasar filaments, respectively. An increase in the filament strength with the extension rate can be substantiated on the basis of the fact that the tensile behavior of silk filament is a time dependent phenomenon due to its visco-elastic nature. Therefore, when a filament is subjected to tensile load, the relaxation time will be higher for lower extension rate than that of higher extension rate. A higher relaxation time obviously allows more stress relaxation, which is responsible for the decrease in stress at certain level of extension for filament tested at lower extension rate as compared to one tested at higher extension rate. On the contrary, less time available for filament rupture allows less stress relaxation at higher extension rate and thereby yields more tenacity $[7,8]$.

The tenacity values of mulberry and tasar silk tested at various gauge lengths are shown in Table 2 . 
Table 2: Tenacity of mulberry and tasar filaments at different gauge lengths

\begin{tabular}{ccc}
\hline $\begin{array}{c}\text { Gauge } \\
\text { length } \\
(\mathrm{mm})\end{array}$ & \multicolumn{2}{c}{ Tenacity (cN/tex) } \\
\hline 20 & $39.8(9.3)$ & $31.6(10.4)$ \\
50 & $39.4(8.2)$ & $30.9(9.6)$ \\
100 & $38.2(6.8)$ & $30.1(6.7)$ \\
250 & $36.5(6.7)$ & $29.7(7.1)$ \\
500 & $35.1(6.4)$ & $29.2(6.2)$ \\
\hline
\end{tabular}

"Values in the parenthesis indicate the $\mathrm{CV} \%$ of tenacity

It is noted that the tenacity of both the silk filaments diminishes with an increase in gauge length. This can be advocated to the presence of flaw in the silk filament, which leads to the localization of stress in excess of theoretical strength, whereby the rupture process is initiated. It thus follows that the fall in strength of silk filament with increasing test length is due to the presence of a distribution of flaw of wide-ranging magnitude, since the probability of encountering a large fatal flaw increases with test length [9.8].

Table 3 shows the number of TPI to break the mulberry and tasar filaments tested at both clockwise and anticlockwise direction of twist.

Table 3: Average TPI to break for mulberry and tasar filaments

\begin{tabular}{ccc}
\hline Type of filament & \multicolumn{2}{c}{$\begin{array}{c}\text { Average number of twists to } \\
\text { break (TPI) }\end{array}$} \\
& $\begin{array}{c}\text { Clockwise } \\
\text { direction }\end{array}$ & $\begin{array}{c}\text { Anticlockwise } \\
\text { direction }\end{array}$ \\
\hline Mulberry filament & $348.8(4.9)^{*}$ & $297.2(7.2)$ \\
Tasar filament & $236.4(6.0)$ & $177.2(8.3)$ \\
\hline
\end{tabular}

"Values in the parenthesis indicate the CV\% of number of twists to break

It can be observed that the number of twists to break the filament in clockwise direction is significantly higher than that of anticlockwise direction for both mulberry and tasar silk. This can be ascribed to the presence of natural convolution of silk in $Z$ direction (i.e., anticlockwise direction), as a result it takes higher turns in clockwise direction to break. The phenomena of untwist as well as twist occurred while rotating the silk filament in clockwise direction in comparison to the only twist phenomenon happened in anticlockwise direction. Therefore, by clockwise rotation the natural convolution of silk filament will open up first and then by further clockwise rotation it would break. In contrast, when a silk filament is rotated in anticlockwise direction, the twist will continually increase and eventually the filament breaks, so the number of twists to break will be less in this case.

It is clearly observed from Table 1 and 2 that the mulberry filament is significantly stronger than that of tasar filament. Furthermore, it is appreciated that the number of twists to cause rupture is again higher for mulberry filament compared to tasar filament (Table 3). The supremacy of mulberry silk in terms of strength and twist to break can be ascribed to its more ordered structure at molecular and morphological levels in comparison to the tasar silk as illustrated in Table 4 [6].

Table 4: Structural properties of mulberry and tasar silk

\begin{tabular}{ccccc}
\hline $\begin{array}{c}\text { Type of } \\
\text { silk }\end{array}$ & $\begin{array}{c}\text { Density } \\
\left(\mathrm{g} / \mathrm{cm}^{3}\right)\end{array}$ & $\begin{array}{c}\text { Birefrin- } \\
\text { gence }\end{array}$ & $\begin{array}{c}\text { Orientation } \\
\text { index }(\%)\end{array}$ & $\begin{array}{c}\text { Sonic } \\
\text { modulus } \\
(\mathrm{cN} / \mathrm{dtex})\end{array}$ \\
\hline Mulberry & 1.3525 & 0.0539 & 85 & 112.2 \\
Tasar & 1.3033 & 0.0165 & 61 & 73.7 \\
\hline
\end{tabular}

Poor orientation in tasar silk is related to the higher percent of bulky groups present in fibroin [6]. Lucas et al. [10] also showed that the ratio of number of amino acids with bulky side groups to the number with short side chains in tasar is almost twice that of mulberry silk.

The filament fracture morphology has been analyzed with the SEM photomicrographs. Some selected tensile and twist fracture morphologies of mulberry and tasar filaments are depicted in Figures 1 and 2, respectively.

It is evident from Figure 1[a] that the tensile fractography of mulberry filament shows a sharp edge as if the filament is cut by a scissor. This can be attributed to the fact that the tensile failure of mulberry filament is possibly propagated by catastrophic mode of rupture. The photomicrograph of tensile failure of tasar filament shows granular surface running across the transverse direction as well as longitudinal cracks on the filament surface (Fig. 2[a]). This could probably be due to the occurrence of partial crack growth in the tasar filament preceding to its catastrophic failure under tensile loading. 


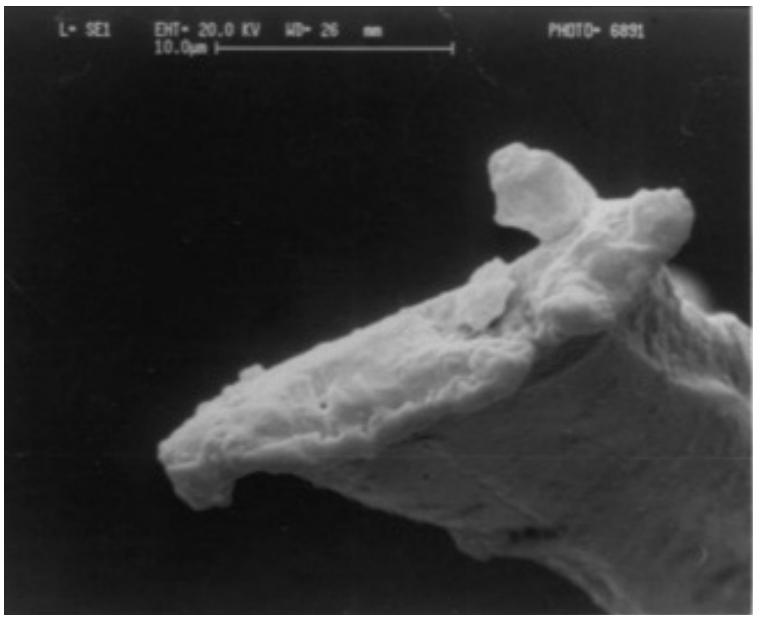

[a]

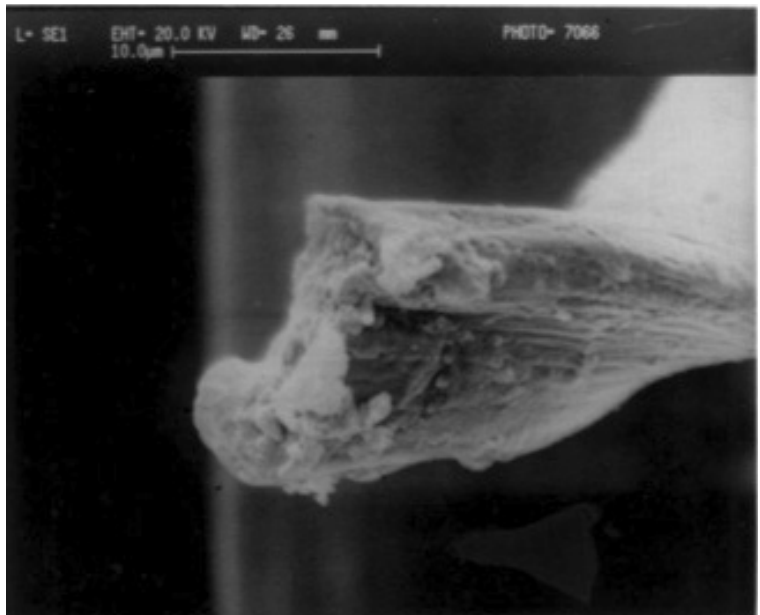

[b]

Figure 1: Tensile and twist fracture morphologies of mulberry filament: (a) tensile failure (extension rate $=200$ $\mathrm{mm} / \mathrm{min}$, gauge length $=100 \mathrm{~mm}$ ), (b) twist failure (turn is given in anticlockwise direction).

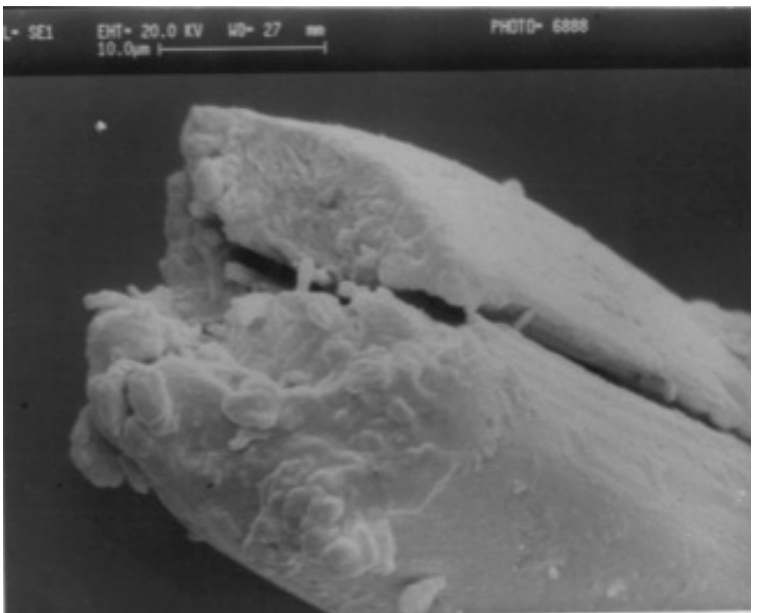

[a]

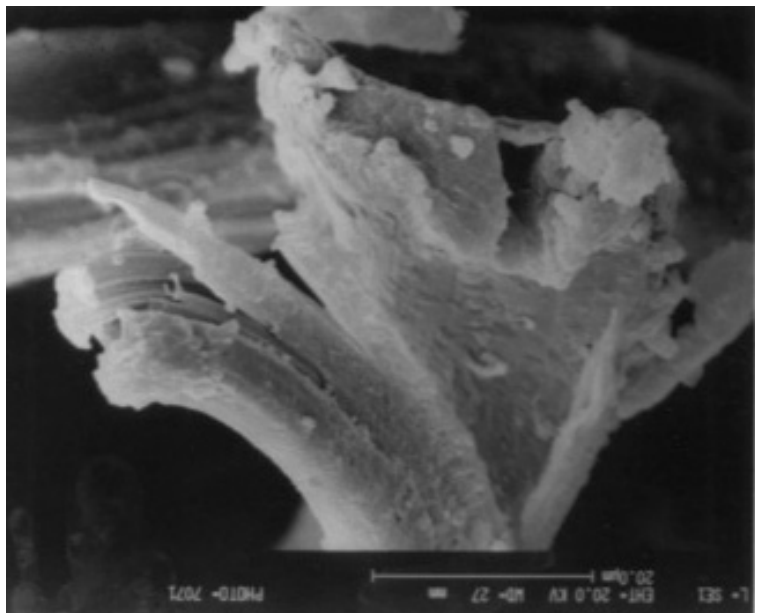

[b]

Figure 2: Tensile and twist fracture morphologies of tasar filament: (a) tensile failure (extension rate $=200$ $\mathrm{mm} / \mathrm{min}$, gauge length $=100 \mathrm{~mm}$ ), (b) twist failure (turn is given in anticlockwise direction).

The twist fractography of mulberry filament shows a wedge shape end (Fig. 1[b]). The filament segments of mulberry filament are separated apart to form wedge shape cross-section due to the bending and shearing while twisting. Furthermore, it is apparent from Figure $1[b]$ that the twist fracture occurs in catastrophic manner in mulberry filament. It is observed from Figure 2[b] that tasar filament shows fraying type of section. In this case the failure is perhaps initiated by breaking of few fibrils owing to shearing and bending and then it is transmitted transversely from one fibrillar component to other. Thus, twist fracture of tasar filament occurs in non-catastrophic mode.

From the foregoing discussion it is obvious that the modes of failure for mulberry and tasar filaments are different. For e.g., the tensile and twist rupture of mulberry filament occur in catastrophic mode as compared to the non-catastrophic mode of tasar filament. This could be due to the better structural integrity of mulberry filament than that of tasar filament as explained in the preceding paragraph.

It can be also noticed from Figures 1 and 2 that there are definite dissimilarities in the mechanisms of tensile and twist failure for silk. The tensile failure occurs when the axial stretch of the filament is higher than its breaking extension, whereas, twist failure is caused by an increasing amount of bending and shearing stretch due to the twisting of filament until it can able to withstand. 


\section{CONCLUSIONS}

The tenacity of mulberry and tasar silk increases with the increase in extension rate. A drop in tenacity is noticed for both the filaments as the gauge length increases. The number of TPI required to break the filament in clockwise direction is appreciably higher than that of anticlockwise direction for both the silk filaments considered in this study. Mulberry filament shows higher strength and it needs more TPI to break as compared to tasar filament. The tensile photomicrograph of mulberry filament displays a sharp edge, but for tasar filament it displays granular surface in the transverse direction in addition to longitudinal cracks on the filament surface. The twist fractography of mulberry filament illustrates a wedge shape, however tasar filament demonstrates fraying type of section. Mulberry silk has different failure mechanism than that of tasar silk.

\section{REFERENCES}

[1] Asakura, T., Kaplan, D. L. (1994). Silk Production and Processing, Encyclopedia of Agricultural Science, 4, $1-11$.

[2] Poza, P., Perez-rigueiro, J., Elices, M., Llorca, J. (2002). Fractographic Analysis of Silkworm and Spider Silk, Engineering Fracture Mechanics, 69, 1035-1048.

[3] Hearle, J. W. S., Lomas, B., Cooke W. D. (1998). Atlas of Fibre Fracture and Damage to Textiles $\left(2^{\text {nd }} E d\right)$, Woodhead Publishing Ltd., Cambridge.

[4] Ghosh, A., Ishtiaque, S. M., Rengasamy, R. S. (2005). Stress-Strain Characteristics of Different Spun Yarns as a Function of Strain Rate and Gauge Length, J. Textile Inst., 96, 99-104.
[5] Hearle, J. W. S., Morton, W. E. (1993). Physical Properties of Textile Fibres ( $\left.3^{r d} E d\right)$, Textile Institute, Manchester.

[6] Das, S., Chattopadhyay, R., Gulrajani, M. L., Sen, K. (2005). Study of Property and Structural Variants of Mulberry and Tasar Silk Filaments, Autex Res. J., 5, 8586.

[7] Vangheluwe, L. (1992). Influence of Strain Rate and Yarn Number on Tensile Test Results, Textile Res. J., 62, 586-589.

[8] Ghosh, A., Ishtiaque, S. M., Rengasamy, R. S. (2005). Analysis of Spun Yarn Failure, Part I:Tensile Failure of Yarns as a function of Structure and Testing $\mathrm{Pa}-$ rameters, Textile Res. J., 75, 731-740.

[9] Peirce, F. T. (1926). Tensile Tests for Cotton Yarns, Part V: The Weakest Link Theorems on the Strength of Long and Composite Specimens, J. Textile Inst., 17, T355-T368.

[10] Lucas, F., Shaw, J. T. B, Smith, S. G. (1955). The Chemical Constitution of Some Silk Fibroins and Its Bearing on Their Physical Properties, J. Textile Inst., 46, T440-452.

Primljeno/Received on: 20.05.2021.

Revidirano/ Revised on: 05.06.2021.

Prihvaćeno/Accepted on: 06.06.2021.

( $) 2021$ Authors. Published by Union of Textile Engineers and Technicians of Serbia. This article is an open access article distributed under the terms and conditions of the Creative Commons Attribution 4.0 International license (CC BY) (https://creativecommons.org/licenses/by/4.0/) 